\title{
Manajemen Asuhan Keperawatan Psikososial Pada Ny. C Dengan Masalah Ketidakberdayaan
}

\author{
Sabran Hadi Pagan \\ sabranhadi99@gmail.com
}

\section{BAB 1 \\ PENDAHULUAN}

\subsection{Latar Belakang}

Stroke merupakan salah satu penyakit yang berbahaya, dapat menyebabkan cacat pada penderita, yang tentu saja akan menghambat produktifitas. Stroke dapat menyebabkan kematian dan menempati urutan ketiga di Indonesia setelah penyakit kanker dan jantung (Susilawati, 2018). Stroke merupakan pembunuh nomor tiga setelah penyakit jantung dan kanker, struke biasanya ditandai dengan kelumpuhan anggota gerak pada salah satu sisi anggota tubuh (Maria, 2020). Berdasarkas Riskesdes pada tahun 2018 angka terjadinya stroke yaitu sebanyak 10,9 per 1.000 peduduk Indonesia. Beberapa kota dengan persentase cukup besar mempunyai penyakit stroke diantaranya Kalimantan Utara $(55,8)$ Aceh $(40,1)$ dan Sumatera Utara $(36,4)$.

Stroke terjadi karena terganggunya suplai darah ke otak yang dikarenakan pecahnya pembuluh darah atau karena tersumbatnya pembuluh darah. Tersumbatnya pembuluh darah menyebabkan terpotongnya suplai oksigen dan nutrisi yang mengakibatkan terjadinya kerusakan pada jaringan otak. Gejala umum yang terjadi pada stroke yaitu wajah, tangan atau kaki yang tiba-tiba kaku atau mati rasa dan lemah, biasanya terjadi pada satu sisi tubuh. Gejala lainnya yaitu pusing, kesulitan untuk berbicara atau mengerti perkataan, kesulitan untuk melihat baik dengan satu mata maupun kedua mata, kesulitan jalan, kehilangan keseimbangan dan koordinasi, pingsan atau 
kehilangan kesadaran, dan sakit kepala yang berat dengan penyebab yang tidak diketahui (Surwaryo, 2019).

Stroke menyebabkan gangguan motorik, gangguan komunikasi verbal, gangguan persepsi, kerusakan fungsi kognitif dan gangguan psikologis serta disfungsi kandung kemih. Menyisakan kelumpuhan, terutama pada sisi yang terkena, timbul nyeri, sublukasi pada bahu, pola jalan yang salah dan banyak evaluasi, orang yang telah mengalami serangan stroke lebih mudah terkena dan dampaknya lebih parah dari serangan pertama dimana angka kematian dan kecactan lebih tinggi sehingga dampak yang akan terjadi pada penderita stroke akan muncul ketidakberdayaan (Amila, 2019).

Ketidakberdayaan merupakan dampak terbesar dari penyakit kronis sebagai hasil dari penerimaan diri dan perubahan gaya hidup pasien dengan penyakit kronis (Ramadia, Keliat \& wardani, 2019). Ketidakberdayaan merupakan perasaan kurang mampu mengendalikan lingkungannya yang membimbing pada sikap menyerah atau putus asa dan mengarahkan atribusi diri yang kuat bahwa dia memiliki ketidakmampuan (Prayogo, 2015).

Ketidakberdayaan adalah pengalaman tentang kurangnya kontrol seseorang terhadap situasi termasuk persepsi bahwa sesuatu tidak akan bermakna mampu mempengaruhi terhadap hasil yang ingin dicapai, seseorang yang mengalami ketidakberdayaan kehilangan kontrol terhadap kejadian dalam hidupnya dan merasa segala sesuatu tidak bermakna bagi dirinya. Perasaan ketidakberdayaan disebabkan pengalaman distress dan perubahan emosional seperti agitasi, frustasi, marah, takut dan cemas. Perasaan ketidakberdayaan yang dialami oleh pasien stroke sering kali disertai depresi, Ketidakberdayaan pada pasien stroke muncul karena pasien stroke cenderung bergantung pada orang lain (Nuraliyah, 2019). Berdasarkan uraian diatas maka penulis tertarik untuk mengambil kasus ketidakberdayaan pada penderita Stroke di Amal Luhur Kec Medan Helvetia. Pertimbangan utama pengambilan kasus ini 
pada Ny. C karena pada kehidupan sehari-hari hanya berbaring ditempat tidur sehingga kondisi ketidakberdayaan akan memperburuk kondisi.

\subsection{Tujuan penulisan}

\section{Tujuan umum}

Untuk memberikan asuhan keperawatan pada Ny. C dengan masalah ketidakberdayaan

\section{Tujuan khusus}

a. Mahasiswa mampu melakukan pengkajian pada Ny. C dengan masalah ketidakberdayaan

b. Mahasiswa mampu melaksanakan diagnosa pada Ny. C dengan masalah ketidakberdayaan

c. Mahasiswa mampu membuat intervensi pada $\mathrm{Ny}$. C dengan masalah ketidakberdayaan

d. Mahasiswa mampu melakukan implementasi pada Ny. C dengan masalah ketidakberdayaan

e. Mahasiswa mampu membuat evaluasi pada Ny. C dengan masalah ketidakberdayaan 


\section{BAB 2}

\section{TINJAUAN TEORI}

\subsection{Konsep Stroke}

\subsubsection{Defenisi Stroke}

Stroke adalah gangguan fungsi otak sebagian atau menyeluruh sebagai akibat dari gangguan aliran darah oleh karena sumbatan atau pecahnya pembuluh darah di otak, sehingga menyebabkan sel-sel otak kekurangan darah, oksigen atau zatzat makanan dan akhirnya dapat terjadi kematian sel-sel. Stroke merupakan penyebab kematian nomor tiga di negara maju setelah penyakit jantung dan kanker pada kelompok usia lanjut, sedangkan di Indonesia menduduki peringkat pertama (Misbach, \& Kalim,2017).

Stroke merupakan penyakit serebrovaskular yang menjadi penyebab utama kematian di Indonesia. Jumlah penderita stroke di seluruh dunia yang berusia dibawah 45 tahun terus meningkat. Badan Kematian akibat stroke diprediksi akan meningkat seiring dengan kematian akibat penyakit jantung dan kanker. Stroke merupakan penyebab kematian tersering ketiga di Amerika dan merupakan penyebab utama disabilitas permanen (Handayani, \& Dominica, 2018). Berdasarkan batasan diatas dapat disimpulkan bahwa, stroke adalah serangan mendadak pada otak karena adanya gangguan fungsi otak sebagian atau bahkan menyeluruh akibat dari sumbatan atau pecahnya pembuluh darah yang ada di otak. Sehingga menyebabkan kelumpuhan pada seseorang.

\subsubsection{Klasifikasi stroke}

Klasifikasi Stroke menurut Nugraha (2017) :

1. Stroke hemoragik

Merupakan perdarahan serebri dan mungkin perdarahan subarachnoid. Disebabkan oleh pecahnya pembuluh darah otak pada daerah otak tertentu. Biasanya kejadiannya saat melakukan aktivitas atau saat aktif, namun bisa juga terjadi saat istirahat. Kesadaran pasien umumnya menurun. Perdarahan otak dibagi tiga, yaitu : 
a. Perdarahan intraserebri (PIS)

Pembuluh Darah (mikroaneurisma) terutama karena hipertensi mengakibatkan darah masuk ke dalam jaringan otak, membentuk massa yang menekan jaringan otak dan menimbulkan edema otak. Peningkatan TIK yang terjadi cepat, dan dapat mengakibatkan kematian mendadak karena herniasi otak. Perdarahan intraserebri yang disebabkan hipertensi sering dijumpai di daerah putamen, thalamus, pons, dan serebellum.

b. Perdarahan subarachnoid (PSA)

Perdarahan ini berasal dari pecahnya aneurisma berry atau AVM. Aneurisma yang pecah ini berasal dari pembuluh darah sirkulasi Willisi dan cabang-cabangnya yang terdapat diluar parenkim otak. Pecahnya arteri dan keluarnya ke ruang subarachnoid menyebabkan TIK meningkat mendadak, meregangnya struktur peka nyeri, dan vasospasme pembuluh darah serebri yang berakibat disfungsi otak global (nyeri kepala, penurunan kesadaran) maupun fokal (hemiparase, gangguan hemisensorik, afasia, dan lainnya).

c. Pendarahan subdural

Perdarahan subdural (termasuk perdarahan subdural akut) pada dasarnya sama dengan perdaran epidural, kecuali bahwa hematoma subdural biasanya jembatan vena robek. Karena periode pembentukan hematoma lebih lama (interval jelas lebih lama) dan menyebabkan tekanan pada otak.

d. Stroke non hemoragik

Jenis stroke ini pada dasarnya disebabkan oklusi pembuluh darah otak yang kemudian menyebabkan terhentinya pasokan dan glukosa ke otak Tidak terjadi perdarahan namun terjadi iskemia yang menimbulkan hipoksia dan selanjutnya dapat timbul edema sekunder. Kesadaran umumya baik. 


\subsubsection{Etiologi}

Penyebab stroke adalah hipertensi (79,2\%), merokok (40,4\%), dislipidemia $(49,4)$, diabetes mellitus $(45,4 \%)$, obesitas $(23,7 \%)$, dan atrial fibrillation (16,5\%). Adapun penyebab stroke Mutiarasari, (2019) yaitu:

1. Trombosis (bekuan darah didalam pembuluh darah otak atau otak).

2. Embolisme serebral (bekuan darah atau material lain yang dibawa ke otak dari bagian tubuh yang lain.

3. Iskemia (penurunan aliran darah ke area otak).

4. Hemoragi serebral (pecahnya pembuluh darah serebral dengan perdarahan ke dalam jaringan otak atau ruang sekitar otak).

\subsubsection{Faktor Resiko Stroke}

Ada beberapa factor resiko terjadinya stroke yaitu : (Pramudita \& Pudjonarko, 2016).)

a. Tekanan darah tinggi atau hipertensi

Pasien dengan hipertensi yang lama akan berpengaruh terhadap kerusakan arteri, penebalan, arterosklerosis atau arteri dapat pecah atau ruftur.

b. Penyakit jantung

Penyakit jantung merupakan factor penyebab yang paling kuat terjadinya stroke iskemik. Jenis penyakit jantung yang menjadi faktor resiko stroke diantaranya penyakit jantung koroner, penyakit katup jantung, gagal jantung, gangguan irama jantung seperti pada fibrilasi atrium yang dapat menyebabkan penurunan kardiac output, sehingga terjadi gangguan perfusi jaringan serebral.

c. Diabetes mellitus

Pada penyakit DM terjadi gangguan atau kerusakan vaskuler baik pada pembuluh darah besar maupun pembuluh darah kecil karena hiperglikemia sehingga aliran darah menjadi lambat, termasuk juga hambatan dalam aliran darah ke otak. 
d. Hiperkolestrol dan lemak

Kolestrol dalam tubuh menyebabkan aterosklerosis pada pembuluh darah otak dan terbentuknya lemak sehingga aliran darah lambat. Disamping itu hiperkolestrol dapat menimbulkan penyakit jantung koroner.

e. Obesitas dan kurang aktivitas

Obesitas dan kurang aktivitas merupakan faktor penyebab terjadinya hiperkolestrol, hipertensi dan penyakit jantung.

f. Usia

Semakin bertambah usia resiko stroke semakin tinggi, hal ini berkaitan dengan elastisitas pembuluh darah.

g. Ras dan keturunan

Stroke lebih sering ditemukan pada kulit putih.

h. Jenis kelamin

Laki-laki memiliki kecenderungan lebih tinggi.

i. Pendidikan Rendah

Rendahnya tingkat pendidikan akan menyebabkan kurangnya informasi kesehatan yang didapatkan, sehingga menyebabkan pengetahuan tentang kesehatan juga kurang seperti pengetahuan tentang penyakit stroke

j. Status Pekerjaan

Seseorang yang tidak bekerja terjadi dalam problem keuangan. Jika tidak bekerja stress memikirkan cara mencari uang untuk memenuhi kebutuhan hidup keluarganya, sehingga pada orang yang tidak bekerja salah satu pemicu terjadinya stroke.

k. Polisitemia

Kadar $\mathrm{Hb}$ yang tinggi (Hb lebih dari $16 \mathrm{mg} / \mathrm{dl}$ ) menimbulkan darah menjadi kental dengan demikian aliran darah ke otak lebih lambat.

1. Perokok

Rokok menimbulkan plaque pada pembuluh darah oleh nikotin sehingga terjadi aterosklerosis. 
m. Alkohol

Pada alkoholik dapat mengalami hipertensi, penurunan aliran darah ke otak dan kardiak aritmia.

n. Kontrasepsi oral dan terapi estrogen

Estrogen diyakini menyebabkan peningkatan pembekuan darah sehingga berisiko terjadinya stroke.

o. Riwayat transient ischemic attacks (TIA)

TIA atau disebut juga ministroke, merupakan gangguan aliran darah otak sesaat yang bersifat reversible. Pasien TIA merupakan tandatanda awal terjadinya stroke dan dapat berkembang menjadi stroke komplit sekitar 10-50\%.

p. Penyempitan pembuluh darah karotis.

Pembuluh darah karotis berasal dari pembuluh darah jantung yang menuju ke otak dan dapat diraba pada leher. Penyempitan pembuluh darah kadang tidak ada gejala dan hanya diketahui dengan pemeriksaan. Penyempitan $>50 \%$ ditemukan pada $7 \%$ pasien lakilaki dan 5\% pada perempuan pada umur diatas 65 tahun. Pemberian obat- obat aspirin dapat mengurangi insiden terjadinya stroke, namun pada beberapa pasien dianjurkan dikerjakan carotid endarterectomi.

\subsubsection{Manifestasi Klinis}

Mendefenisikan stroke merupakan suatu tanda klinis yang berkembang cepat akibat gangguan otak fokal (atau global) dengan gejala - gejala yang berlangsung selama 24 jam atau lebih dan dapat menyebabkan kematian tanpa adanya penyebab lain yang jelas selain vaskuler. Manifestasi klinik stroke tergantung dari sisi atau bagian mana yang terkena, rata-rata serangan, ukuran lesi dan adanya sirkulasi kolateral. Pada stroke akut gejala klinik meliputi Kabi, Tumewah \& Kembuan, (2015).

1. Kelumpuhan wajah atau anggota badan sebelah (hemiparesis) atau hemiplegia (paralisis) yang timbul secara mendadak. Kelumpuhan 
terjadi akibat adanya kerusakan pada area motoric di korteks bagian frontal, kerusakan ini bersifat kontralateral artinya jika terjadi kerusakan pada hemisfer kanan makan kelumpuhan otot pada sebalah kiri. Pasien juga akan kehilangan kontrol otot volunteer dan sensorik sehingga pasien tidak dapat melakukan ekstensi maupun fleksi.

2. Gangguan sensibilitas pada satu atau lebih anggota badan. Gangguan sensibilitas terjadi karena kerusakan system saraf otonom dengan gangguan saraf sensorik.

3. Penurunan kesadaran (konfusi, delirium, letargi, stupor atau koma), terjadi akibat perdarahan, kerusakan otak kemudian menekan batang otak atau terjadinya gangguan metabolik otak akibat hipoksia.

4. Afasia (kesulitan dalam bicara) Afasia adalah defisit kemampuan komunikasi bicara, termasuk dalam membaca, menulis memahami bahasa. Afasia terjadi jika terdapat kerusakan pada area pusat bicara primer yang berada pada hemisfer kiri dan biasanya terjadi pada stroke dengan gangguan pada arteri middle serebral kiri. Afasia dibagi menjadi 3 yaitu afasia motorik, sensorik dan afasia global. Afasia motorik atau ekspresif terjadi jika pada area Broca, yang terletak pada lobus frontal otak. Pada afasia jenis ini pasien dapat memahami lawan bicara tetapi pasien tidak dapat mengungkapkan dan kesulitan dalam mengungkapkan bicara. Afasia sensorik terjadi karena kerusakan pada area Wernicke, yang terletak pada lobus temporal. Pada afasia sensorik pasien tidak mampu menerima stimulasi pendengaran tetapi pasien mampu mengungkapkan pembicaraan. Sehingga respon pembicaraan pasien tidak koheren.

5. Disartria (bicara cadel atau pelo) Merupakan kesulitan bicara terutama dalam artikulasi sehingga ucapannya menjadi tidak jelas. Namun demikian pasien dapat memahami pembicaraan, menulis, 
mendengarkan mampu membaca. Disartria terjadi karena kerusakan nervus kranial sehingga terjadi kelemahan dari otot bibir, lidah dan laring. Pasien juga terdapat kesulitan dalam mengunyah dan menelan.

6. Gangguan penglihatan, diplopia. Pasien dapat kehilangan penglihatan atau juga pandangan menjadi ganda, gangguan lapang pandang pada salah satu sisi. Hal ini terjadi karena kerusakan lobus temporal atau parietal yang dapat menghambat serat saraf optik pada korteks oksipital. Gangguan penglihatan juga dapat disebabkan karena kerusakan pada saraf kranial III, IV, dan VI.

7. Disfagia atau kesulitan menelan terjadi karena kerusakan nervus kranial IX, selama menelan bolus didorong oleh lidah dan glottis menutup kemudian makanan masuk ke esophagus.

8. Inkontinensia baik bowel maupun bladder sering terjadi karena terganggunya saraf yang mensarafi bladder dan bowel.

9. Vertigo, mual, muntah, dan nyeri kepala, terjadi kerena peningkatan tekanan intracranial, edema serebri.

\subsubsection{Penatalaksanaan}

Penatalaksanaan umum sama dengan pada stroke, tukak lambung diatasi dengan antagonis $\mathrm{H} 2$ parenteral, sukralfat, atau inhibitor pompa proton; komplikasi saluran napas dicegah dengan fisioterapi dan diobati dengan antibiotik spektrum luas. Terapi khusus: Neuroprotektor dapat diberikan kecuali yang bersifat vasodilator. Tindakan bedah mempertimbangkan usia dan letak perdarahan yaitu pada pasien yang kondisinya kian memburuk dengan perdarahan serebelum berdiameter $>3 \mathrm{~cm} 3$, hidrosefalus akut akibat perdarahan intraventrikel atau serebelum, dilakukan VP-shunting, dan perdarahan lobar >60 ml dengan tanda peningkatan tekanan intrakranial akut dan ancaman herniasi Hamzah, (2015) : 
1. Pada Fase Akut

a. Pertahankan jalan nafas, pemberian oksigen, penggunaan ventilator.

b. Monitor peningkatan tekanan intracranial.

c. Monitor fungsi pernafasan : Analisa Gas Darah

d. Monitor jantung dan tanda-tanda vital, pemeriksaan EKG.

e. Evaluasi status cairan dan elektrolit

f. Kontrol kejang jika ada dengan pemberian antikonvulsan, dan cegah resiko injuri.

g. Lakukan pemasangan NGT untuk mengurangi kompresi lambung dan pemberian makanan.

h. Cegah emboli paru tromboplebitis dengan antikoagulan.

i. Monitor tanda-tanda neurologi seperti tingkat kesadaran, keadaan pupil, fungsi sensorik dan motoric, nervus kranial dan refleks.

2. Fase Rehabilitasi

a. Pertahankan nutrisi yang adekuat

b. Program managemen bladder dan bowel

c. Mempertahankan keseimbangan tubuh dan rentang gerak sendi (ROM)

d. Pertahankan integritas kulit

e. Pertahankan komunikasi yang efektif

f. Pemenuhan kebutuhan sehari-hari (ADL)

g. Persiapan pasien pulang.

3. Pembedahan

Dilakukan jika perdarahan serebrum diameter lebih dari $3 \mathrm{~cm}$ atau volume lebih dari $50 \mathrm{ml}$ untuk dekompresi atau pemasangan pintasan ventrikulo-peritoneal bila ada hidrosefalus obstruktif akut.

4. Terapi Obat-obatan

Terapi pengobatan tergantung dari jenis stroke.

1. Stroke Iskemia

a. Pemberian trombolisis dengan rt-PA (recombinant tissue 
plasminogen).

b. Pemberian obat-obatan jantung seperti digoksin pada aritmia jantung atau alfa beta, kaptopril, antagonis kalsium pada pasein dengan hipertensi.

2. Stroke Hemoragik

a. Antihipertensi : Kaptopril, antagonis kalsium

b. Diuretik : Manitol 20\%, furosemide

c. Antikonvulsan: fenitoin

Penatalaksanaan pasien stroke meliputi tiga hal, yaitu mengurangi kerusakan neurologik lebih lanjut, menurunkan angka kematian dan ketidakmampuan gerak pasien (immobility) dan kerusakan neurologik serta mencegah serangan berulang (kambuh). Kebanyakan pasien stroke menerima obat polifarmasi karena sebagian besar pasien stroke mengalami komplikasi. Untuk mendapatkan outcome terapi yang baik pada pasien stroke yang menjalani pengobatan diperlukan kerjasama multidisiplin ilmu antara dokter, perawat, farmasis dan tenaga kesehatan lain, bahkan keluarga pasien (Handayani, \& Dominica, 2018).

\subsection{Konsep Ketidakberdayaan}

\subsubsection{Defenisi Ketidakberdayaan}

Ketidakberdayaan merupakan persepsi individu bahwa segala tindakan akan mendapatkan hasil atau suatu keadaan individu kurang dapat mengendalikan kondisi tertentu atau kegiatan yang baru dirasakan (Pardede,2020). Ketidakberdayaan merupakan persepsi atau tanggapan seseorang bahwa perilaku atau tindakan yang sudah dilakukan nya tidaknya akan membawa hasil yang diharapkan atau tidak akan membawa perubahan hasil seperti yang diharapkan, sehingga seseorang sulit mengendalikan situasi yang akan terjadi (wahyudi, 2020). Ketidakberdayaan merupakan kondisi seseorang yang merasa kurang mengontrol kejadian, pribadi, ataupun situasi yang memberi dampak pada pandangan tujuan dan gaya hidup (Yusuf, 2015). 
Ketidakberdayaan adalah pengalaman tentang kurangnya kontrol seseorang terhadap situasi persepsi bahwa sesuatu tidak akan bermakna mampu mempengaruhi terhadap hasil yang ingin dicapai (Jannah, 2015). Ketidakberdayaan dapat muncul akibat kebiasaan dimasa lampau dan perubahan kemampuan fisik akibat penyakit (Ummah, 2018).

Ketidakberdayaan adalah suatu kondisi dimana individu merasa tidak mampu menahan segala hal menyakitkan dan tidak nyaman yang dialami oleh dirinya sendiri (Azari, 2020)

\subsubsection{Etiologi Ketidakberdayaan}

Etiologi ketidakberdayaan menurut (Tim Pokja SDKI DPP PPNI, 2017) antara lain :

1. Program pengobatan/perawatan yang mempunyai jangka panjang

2. Lingkungan yang tidak mendukung dalam pengobatan/perawatan.

3. Interaksi interpersoanal yang tidak memuaskan

Ketidakberdayaan disebabkan karena kurangnya pengetahuan, ketidakadekuatan koping sebelumnya (seperti: Depresi), serta kurangnya kesempatan dalam membuat keputusan (Novi, 2017). Faktor yang berhubungan dengan ketidakberdayaan menurut (Novi, 2017) yaitu:

a. Kesehatan lingkungan : hilangnya privasi dan kontrol terhadap terapi

b. Hubungan interpersonal: penyalahgunaan kekuasaan dan hubunganyang kasar.

c. Penyakit yang berhubungan dengan rejimen: penyakit kronis atau yang melemahkan kondisi. Hal tersebut menyebabkan seseorangtidak dapat melakukan kegiatan aktivitas fisik dan juga tidak mampu melaksanakan tanggung jawab serta menjalankan perannya. 


\subsubsection{Patofisiologi Ketidakberdayaan}

Pada patafisiologi dengan masalah ketidakberdayaan saat ini belumdapat diketahui secara pasti, namun jika dilakukan analisis dari proses terjadinya ketidakberdayaan berasal dari seseorang individu yang tidak mampu mengatasi suatu masalah sehingga menyebabkan stress yang hal tersebut diawali dalam perubahan dalam respon otak yang menafsirkan perubahan didalam otak. Stress tersebut akan menyebabkan korteks serebri yang akan mengirimkan sinyal menuju hipotalamus, yang kemudian seharusnya ditangkap system limbic yang dimana salah satu bagian pentingnya merupakan amigdala itu akan bertanggung jawab didalam status emosional individu akibat dari keaktifan system hipotalamus pituitary adrenal (HPA) dan kemudian menyebabkan rusaknya pada hipotalamus menjadikan seseorang kehilangan mood dan juga motivasi dan akhirnya menyebabkan seseorang untuk malas melakukan sesuatu,hambatan emosional dengan pasien yang mengalami ketidakberdayaan, terkadang dapat berubah menjadi murung dan sedih sehingga menyebabkan seseorang itu merasa tidak berguna lagi, dan merasa hidupnya telah gagal (Sarani, 2021)

\subsubsection{Kondisi Klinis Ketidakberdayaan}

Diagnosa yang tidak terduga atau baru, Peristiwa traumatis, Diagnosis penyakit kronis, Diagnosis penyakit terminal dan Rawat inap menurut SDKI (2018).

\subsubsection{Tanda dan Gejala}

1. Batasan kararakteristik SDKI :

a. Mayor

Subjektif : Menyatakan frustasi atau tidak mampu melaksanakan aktivitas sebelumnya

Objektif : Bergantung pada orang lain 
b. minor :

Subjektif : Merasa diasingkan, Menyatakan keraguan tentang kinerja peran, Menyatakan kurang kontrol, Menyatakan rasa malu dan Merasa tertekan (depresi).

Objektif : Tidak berpartisipasi dalam perawatan dan Pengasingan

2. Batasan karakteristik pasien dengan ketidakberdayaan. ketidakberdayaan yang dialami pasien terdiri dari energi dan tingkatan yaitu:

a. Rendah Pasien akan mengungkapkan ketidakpastian tentang fluktuasi tingkat energi dan bersikap positif.

b. Sedang Pasien akan mengalami ketergantungan kepada orang lain yang dapat mengakibatkan ititabilitas, ketidaksukaan dan rasa bersalah.

c. Berat Pasien akan menunjukan sikap apatis, depresi terhadap perubahan dalam dirinya yang telah terjadi.

\subsubsection{Faktor Predisposisi}

Faktor predisposisi merupakan suatu faktor resiko yang menjadi sumber utama stress dan memiliki pengaruh dalam tipe dan sumber individu untuk menghadapi stess secara biologis, psikologis dan sosial budaya, Faktor predisposisi tersebut antara lain :

a. Biologis

1. Riwayat keturunan

2. Gaya hidup (Merokok, Alkohol dan zat adiktif)

3. Penderita penyakit kronis ( stroke, diabetes melitus)

4. Memeliki riwayat penyakit jantung paru-paru yang mengaktivitasnya sehari-hari pasien.

5. Memiliki riwayat menderita penyakit secara progresif menimbulkan ketidakmampuan (Stroke, kanker terminal dan Aids) 
b. Psikologis

1. Memiliki pengalaman perubahan didalam gaya hidup akibat lingkungan tempat tinggal

2. Ketidakmampuan dalam mengambil suatu keputusan serta mempunyai kempuan untuk melakukan komunikasi verbal yang kurang atau tidak mampu untuk mengekspresikan perasaan yang dirasakan terkait dengan penyakit atau kondisi yang sedang terjadi.

3. Tidak mampu menjalankan peran akibat suatu penyakit secara progresif menimpulkan ketidakmampuan (stroke, kanker terminal dan AIDS).

4. Merasa kurang puas dengan kehidupan yang telah dijalani (merasatujuan hidupnya tidak tercapai).

5. Merasa frustasi dengan keadaan kesehatannya dengan kondisi yangbergantung dengan orang lain.

6. Self control : sulit untuk mengontrol rasa emosi, merasa cemas, merasatakut, gaya hidup yang tidak berdaya

c. Social budaya

1. Pendidikan rendah.

2. Kurang aktif didalam kegiatan masyarakat.

3. Hilangnya kemampuan dalam melakukan aktivitas akibat proses penuaan (pension, defitit memori, defisit motoric dan status finansial).

4. Cenderung bergantung dengan orang lain, tidak dapat berpartisipasi dalam social kemasyarakat 


\subsubsection{Faktor presipitasi}

Faktor presipitasi merupakan suatu kondisi internal seorang pasien dimana pasien tersebut kkurang dapat menerima perubahan fisiknya dan psikologis yang telah terjadi. Kondisi eksternal biasanya dari pihak keluarga dan masyarakat kurang mendukung (Sarani, 2021). Faktorfaktor lain yang berhubungan dengan faktor presipitasi yang akan timbul ketidakbaerdayaan antara lain :

a. Biologis

1. Seseorang menderita suatu penyakit dan harus melakukan tindakanterapi tertentu, pengobatan terkait dengan penyakit (jangka panjang, sulit dan kompleks).

2. Penyakit kronis yang kambuh dalam 6 bulan terakhir.

3. Kurang mampu menyusaikian diri dengan budaya, ras etnik dangender.

4. Adanya perubahan didalam diri (fisik).

b. Psikologis

1. Perubahan gaya hidup akaibat memiliki penyakit kronis.

2. Tidak dapat melakukan aktivitas sendiri kemudian timbullah keputusasaan.

3. Perasaan malu serta rendah diri karena aktivitas bergantung dengan orang lain.

4. Kehilangan rasa mandiri atau ketergantungan dengan orang lain.

c. Social budaya

1. Kehilangan pekerjaan karena kondisi kesehatan sekarang.

2. Kehilangan kemampuan dalam melakukan aktivitas dari prosespenuaan (pensiun, defisit memori, defisit motoric dan status finansial).

3. Terdapat perubahan status kuratif menjadi status paliatif.

4. Tidak dapat melakukan kegiatan agama dan tidak mampu melakukanpartisipasi dengan masyarakat. 


\subsection{Konsep Asuhan Keperawatan}

\subsubsection{Pengkajian}

Pengkajian adalah tahap awal dari sebuah proses keperawatan dan juga merupakan proses sistematis yang dilakukan untuk mengumpukan data dari berbagai sumber, yang digunakan untuk mengevaluasi dan mengidentifikasi status kesehatan seorang pasien. Pengkajian yang lengkap, akurat, sesuai dengan kejadian atau kenyataan kebenaran dalam data ini sangat diperlukan untuk merumuskan diagnosa keperawatan dan juga digunakan dalam pemberian pelayanan kesehatan sesuai dengan respon masingmasing individu yang kemudian telah ditentukan dalamstandar praktik keperawatan.

\section{Identitas Pasien}

Meliputi nama pasien nama yang bertanggung jawab, alamat, nomor register, agama, pendidikan, tanggal masuk rumah sakit dan diagnosa medis

\section{Keluhan utama}

Biasanya pasien menyatakan perasaan frustasi atau mengungkapkan bahwa dia tidak mampu melakukan aktivitas sehari-hari seperti sebelumnya layaknya orang yang sehat, pasien merasa sangat bergantung dengan orang yang lain (Tim Pokja SDKI DPP PPNI, 2017)

\section{Riwayat sekarang}
a. Riwayat kesehatan sekarang
b. Riwayat kesehatan dahulu
b. Riwayat kesehatan psikologi
c. Riwayat kesehatan keluarga

\subsubsection{Diagnosa Keperawatan}
a. ketidakberdayaan
b. kecemasan
c. Penampilan tidak efektif 


\subsubsection{Intervensi Ketidakberdayaan}

\section{Tujuan Intervensi Keperawatan}

a. Tujuan Umum: Pasien Menunjukkan kepercayaan kesehatan dengan keriteria: merasa mampu melakukan, merasa dapat mengendalikan dan merasakan ada sumber-sumber

b. Tujuan Khusus : Pasien menunjukkan partisipasi: keputusan perawatan kesehatan ditandai dengan

1. Mengungkapkan dengan kata-kata tentang segala perasaan ketidakberdayaan.

2. Mengidentifikasi tindakan yang berada dalam kendalinya

3. menghubungkan tidak adanya penghalang untuk bertindak

4. Mengungkapkan dengan kata-kata kemampuan untuk melakukan tindakan yang diperlukan

5. Melaporkan dukungan yang adekuat dari oramg terdekat, termasuk teman dan tetangga

6. Melaporkan waktu, keuangan pribadi dan ansuransi kesehatan yang memadai

7. Melaporkan ketersediaan alat, bahan, pelayanan dan transportasi

\section{Rencana Tindakan}

a. Bantu pasien untuk mengidentifikasi faktor-faktor yang dapat berpengaruh pada ketidakberdayaan (misalnya: pekerjaan, aktivitas hiburan, tanggung jawab peran, hubungan antar pribadi). Rasional: mengidentifikasi situasi/hal-hal yang berpotensi dapat dikendalikan dan dapat digunakan sebagai sumber kekuatan bagi pasien.

b. Diskusikan dengan pasien pilihan yang realistis dalam perawatan, berikan penjelasan untuk pilihan tersebut. 
Rasional: Memberikan kesempatan pada pasien untuk berperan dalam proses perawatan, termasuk untuk meningkatkan pemikiran positif pasien, dan meningkatkan tanggung jawab pasien.

c. Libatkan pasien dalam pembuatan keputusan tentang rutinitas perawatan/rencana terapi

Rasional: Pelibatan pasien dalam proses pembuatan keputusan, mampu meningkatkan rasa percaya diri.

d. Jelaskan alasan setiap perubahan perencanaan perawatan kepada pasien (jelaskan semua prosedur, peraturan dan pilihan untuk pasien, berikan waktu untuk menjawab pertanyaan dan minta individu untuk menuliskan pertanyaan sehingga tidak terlupakan) Rasional: Meningkatkan kemampuan berpikir positif terhadap proses perawatan yang sedang dijalani oleh pasien, pelibatan pasien dalam setiap pengambilan keputusan menjadi hal penting.

e. Bantu pasien mengidentifikasi situasi kehidupannya yang dapat dikendalikan (perasaan cemas, gelisah, ketakutan).

Rasional: Kondisi emosi pasien mengganggu kemampuannya untuk memecahkan masalah. Bantuan diperlukan agar dapat menyadari secara akurat keuntungan dan konsekuensi dari alternative yang ada.

f. Bantu pasien mengidentifikasi situasi kehidupan yang tidak dapat ia kendalikan (adiksi), Disukusikan dan ajarkan cara melakukan manipulasi menghadapi kondisikondisi yang sulit dikendalikan, misalnya afirmasi.

Rasional: Dorong pasien untuk mengungkapkan perasaan yang berhubungan dengan ketidakmampuan sebagai upaya mengatasi masalah yang tidak terselesaikan dan menerima hal-hal yang tidak dapat diubah.

g. Bantu pasien mengidentifikasi faktor pendukung, kekuatan kekuatan diri (misalnya kekuatan baik itu berasal dari diri sendiri, keluarga, orang terdekat, atau teman). 
Rasional: Pada pasien dengan ketidakberdayaan dibutuhkan faktor pendukung yang mampu mensupport pasien, dari dalam sendiri dapat berupa penguatan nilai-nilai spiritual, Jika dalam proses perawatan kekuatan lain tidak adekuat.

h. Sampaikan kepercayaan diri terhadap kemampuan pasien untuk menangani keadaan dan sampaikan perubahan positif dan kemajuan yang dialami pasien setiap hari.

Rasional: Meningkatkan rasa percaya diri terhadap kemampuan atas upaya dan usaha yang sudah dilakukan oleh pasien.

i. Biarkan pasien mengemban tanggung jawab sebanyak mungkin atas praktik perawatan dirinya. Dorong kemandirian pasien, tetapi bantu pasien jika tidak dapat melakukannya.

Rasional: memberikan pilihan kepada pasien akan meningkatkan perasaannya dalam mengendalikan hidupnya.

j. Berikan umpan balik positif untuk keputusan yang telah dibuatnya.

\subsubsection{Implementasi}

Implementasi merupakan suatu tahap pelaksanaan terhadap suatu rencana tindakan keperawatan yang telah ditetapkan untuk perawat bersama seorang pasien. Implementasi dapat dilakukan sesuai dengan rencana yang telah dibuat setelah validasi, selain itu juga dibutuhkan keterampilan interpersonal, intelektual, dan tehnik yang dilakukan harus dengan cermat serta efisien dengan sitiasi yang tepat dan dengan selalu memperhatikan keamanan fisik maupun psikologis. Setelah sudah selesai melakukan implementasi, lakukan dokumentasi yang akan meliputi intervensi yang sebelumnya sudah dilakukan dan tanyakan bagaimana respon pasien (Sarani, 2021)

\subsubsection{Evaluasi}

Evaluasi merupakan tahap terakhir dalam proses keperawatan. Evaluasi ini adalah kegiatan membandingkan hasil yang telah dicapai setelah 
dilakukan implementasi keperawatan dan memiliki tujuan yang diharapakan dalam perencanaan. Perawat pun mempunyai tiga alternative dalam menetukan sejauh mana tujuan itu dapat tercapai :

1. Berhasil : perilaku pasien sesuai dengan pertanyaan tujuan dalam waktu dan tujuan yang telah ditetapkan . Tercapai sebagian : pasien telah menunjukan perilaku tetapi belum sebaik dengan perilaku yang telah ditentukan dalam pertanyaan tujuan.

2. Belum tercapai : pasien belum mampu sama sekali menunjukkan perilaku yang telah diharapkan sesuai dengan pernyataan tujuan (Sarani, 2021). Agar memudahkan perawat dalam mengevaluasi atau membuat perkembangan pasien maka digunakan komponen SOAP yaitu :

S : Data subyektif merupakan perkembangan suatu keadaan pasien yang didasarkan pada apa yang telah dirasakan, dikeluhkan dan yang diungkapkan.

O : Data obyektif merupakan perkembangan yang dapat diamati dan juga dapat diukur oleh seorang perawat atau tim kesehatan yang lainnya

A : Analisis merupakan penelitian dari kedua jenis data tersebut baik data subjektif maupun data objektif, apakah berkembang dengan baik atau malah kemunduran.

$\mathrm{P}$ : Perencanaan merupakan rencana dalam penanganan pasien yang didasari pada hasil analisis diatas yang mempunyai isi untuk melanjutkan perencanaan apabila masalah belum teratasi 


\section{BAB 3}

\section{TINJAUN KASUS}

\subsection{Pengkajian Keperawatan}

\begin{tabular}{|l|c|}
\hline Nama : Ny .C & Kondisi saat ini : \\
Usia : 56 tahun & Ny. C mengatakan badannya lemas dan anggota gerak atas dan bawah kanan \\
Tahun no reg : - & masih tidak bisa digerakkan, pasien mengatakan tidak bisa melakukan kegiatan \\
Ruangan : - & seperti dulu lagi dan merasa tidak berdaya akibat penyakitnya, pasien \\
Tgl masuk rs: - & mengatakan kondisi ini membuat Ny. C merasa sangat kecewa, dan cemas \\
Tgl pengkajian : 5 oktober 2021 & karena pasien tidak dapat beraktivitas seperti sebelumnya, pasien merasa malu, \\
Alamat : Jalan Amal luhur kec & juga merasa seperti diasingkan oleh keluarganya, dan takut selalu sering \\
medan helvetia & merepotkan keluarga, dan anaknya karena kegiatan sehari-hari seprti BAK, \\
Kondisi Utama : lemas, kesemutan, anggota & BAB harus dibantu oleh anak dan cucunya \\
gerak atas dan bawah kanan masih tidak bisa & \\
digerakkan & \\
& \\
& \\
&
\end{tabular}

3.1.1 Faktor Predisposisi Dan Faktor Presipitasi 


\begin{tabular}{|c|c|c|c|c|}
\hline \multirow[t]{2}{*}{ Faktor predisposisi } & \multicolumn{3}{|l|}{ Faktor presipitasi } & \multirow[t]{2}{*}{ STRESSOR } \\
\hline & Nature & Origin & $\begin{array}{l}\text { Number \& } \\
\text { Timing }\end{array}$ & \\
\hline $\begin{array}{l}\text { Biologis: } \\
\text { 1. Stroke } \\
\text { 2. Ny. C menderita diabetes melitus } 1 \text { tahun yang lalu } \\
\text { 3. Ny. C sering mengkonsumsi coffe } \\
\text { 4. Ny. C tidak rutin check up kepelayanan kesehatan }\end{array}$ & $\begin{array}{l}\text { Badan lemas, } \\
\text { kesemutan, gatal, } \\
\text { gemetaran pusing, } \\
\text { Kadar glukosa darah } \\
\text { tinggi }\end{array}$ & Internal & $\begin{array}{lr}\text { Sejak } & 2 \\
\text { minggu } & \text { yang } \\
\text { lalu } & \end{array}$ & - Stroke \\
\hline $\begin{array}{l}\text { Psikologis : } \\
\text { 1. Ny. C memiliki kepribadian yang terbuka setiap ada } \\
\text { masalah akan dibicarakan dengan suaminya } \\
\text { 2. Ny. C malu karena tidak bisa melakukan akivitas } \\
\text { dengan baik } \\
\text { 3. Merasa kecewa akan penyakitnya yang ia derita } \\
\text { 4. Pasien merasa seperti diasingkan }\end{array}$ & 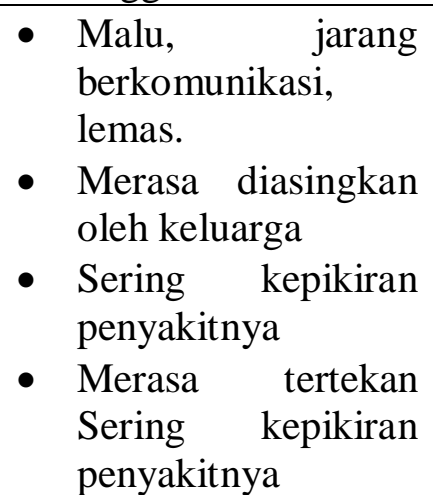 & Internal & $\begin{array}{lr}\text { Sejak } & 2 \\
\text { minggu } & \text { yang } \\
\text { lalu } & \end{array}$ & $\begin{array}{ll}\text { - } & \text { Cemas, takut } \\
& \text { panikan, kwatir }\end{array}$ \\
\hline $\begin{array}{l}\text { Sosiocultural : } \\
\text { 1. Ny. C seorang perempuan umur } 56 \text { tahun } \\
\text { 2. Ny . C menikah dan memiliki } 2 \text { orang anak } \\
\text { 3. Ny.C merupakan ibu rumah tangga } \\
\text { 4. Sebelumnya Ny.C aktif terlibat dalam kegiatan } \\
\text { dilingkungan tempat tinggal seperti perwiritan atau }\end{array}$ & 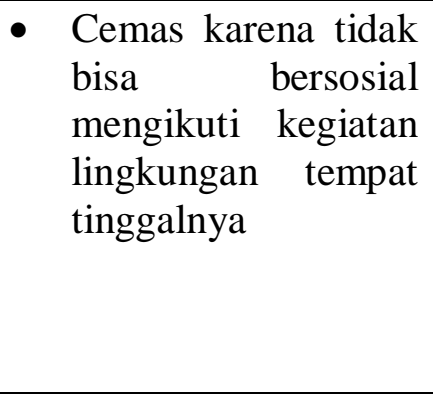 & Eksternal & $\begin{array}{lr}\text { Sejak } & 2 \\
\text { minggu } & \text { yang } \\
\text { lalu } & \end{array}$ & Cemas \\
\hline
\end{tabular}




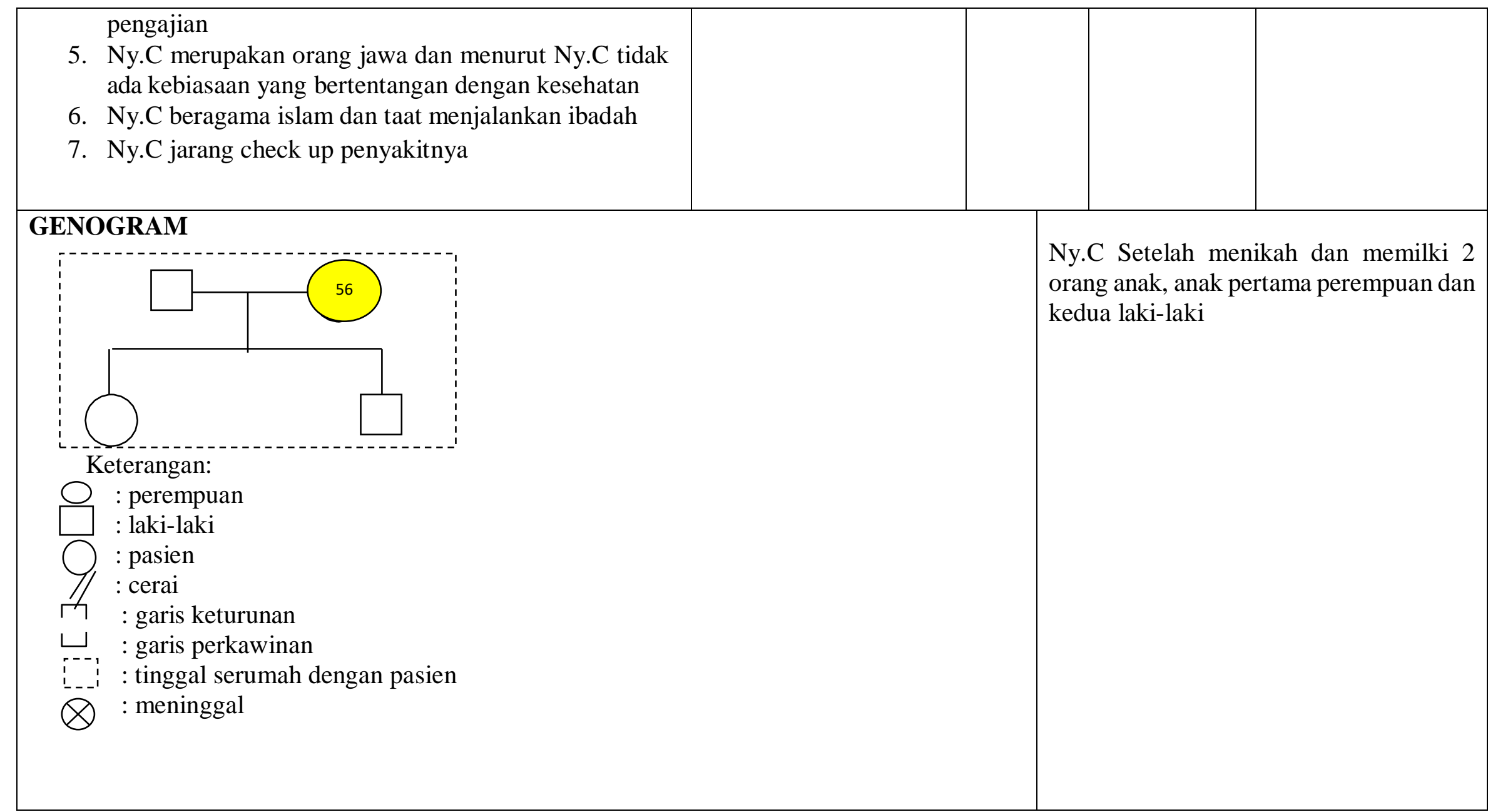

3.1.2 Penilaian (Respon)Terhadap Stressor 


\begin{tabular}{|c|c|c|c|c|c|c|}
\hline STRESSOR & KOGNITIF & AFEKTIF & FISIOLOGIS & PERILAKU & SOSIAL & $\begin{array}{l}\text { DIAGNOSA } \\
\text { KEPERAWATAN }\end{array}$ \\
\hline $\begin{array}{l}\text { BIOLOGIS } \\
\text { - (Stroke ) }\end{array}$ & $\begin{array}{l}\text { - Menurut Ny.C } \\
\text { penyakit Stroke } \\
\text { diakibatkan } \\
\text { karena coffe } \\
\text { - Menganggap } \\
\text { penyakit yang } \\
\text { diderita serius } \\
\text { - Tidak tahu apa } \\
\text { yang harus } \\
\text { dilakukan untuk } \\
\text { penyakitnya }\end{array}$ & $\begin{array}{l}\text { - Ny.C merasa } \\
\text { malu,sedih } \\
\text { dan bingung } \\
\text { dengan } \\
\text { kondisi } \\
\text { penyakitnya }\end{array}$ & \begin{tabular}{|l} 
- Pusing \\
- Sulit tidur \\
makan nafsu \\
- Ny.C tampak \\
lemas \\
- Pemeriksaan \\
TTV \\
TD: $150 / 90$ \\
mmhg \\
$\mathrm{N}: 88 \mathrm{x} /$ menit \\
$\mathrm{P}: 22 \mathrm{x} /$ menit \\
S: $37{ }^{0} \mathrm{C}$ \\
Kgd sewaktu : 200 \\
$\mathrm{mg} / \mathrm{dl}$
\end{tabular} & $\begin{array}{l}\text { - Ny.C jarang } \\
\text { kontrol ke } \\
\text { rumah sakit } \\
\text { Ekspresi } \\
\text { muka lesu } \\
\text { - Ny.C tampak } \\
\text { lemas dan } \\
\text { gemetaran }\end{array}$ & $\begin{array}{l}\text { - Pasien } \\
\text { mendatangi dan } \\
\text { menggunakan } \\
\text { fasilitas } \\
\text { kesehatan yang } \\
\text { ada untuk } \\
\text { mencari } \\
\text { kesembuhan } \\
\text { terhadap } \\
\text { masalah yang } \\
\text { dihadapi saat } \\
\text { ini }\end{array}$ & - Ketidak berdayaan \\
\hline
\end{tabular}




\begin{tabular}{|c|c|c|c|c|c|c|}
\hline $\begin{array}{l}\text { PSIKOLOGIS } \\
\text { - sedih, cemas, } \\
\text { kesal dan } \\
\text { bingung } \\
\text { dengan kondisi } \\
\text { penyakit dan } \\
\text { pengobata } \\
\text { n serta } \\
\text { perawatannya }\end{array}$ & $\begin{array}{l}\text { - Ny.C tidak tahu } \\
\text { bahwa badannya } \\
\text { menjadi lemah, } \\
\text { gemetaran dan } \\
\text { luka yang lama } \\
\text { sembuh } \\
\text { merupakan } \\
\text { dampak dari } \\
\text { penyakit yang } \\
\text { diderita } \\
\text { - Ny.C mengaku } \\
\text { bosan di rumah } \\
\text { sakit tidak tahu } \\
\text { Ny.C tida } \\
\text { pengobatan } \\
\text { seperti apa lagi } \\
\text { yang dapat } \\
\text { dilakukan untuk } \\
\text { mengobati } \\
\text { penyakitnya }\end{array}$ & $\begin{array}{l}\text { - Merasa kesal } \\
\text { dengan } \\
\text { penyakitnya } \\
\text { yang tidak } \\
\text { sembuh- } \\
\text { sembuh }\end{array}$ & $\begin{array}{l}\text { - Pusing } \\
\text { - Mual } \\
\text { - Sulit tidur dan } \\
\text { sering } \\
\text { terbangun } \\
\text { apabila tidur } \\
\text { - Bahu terasa } \\
\text { tegang } \\
\text { - Tidak nafsu } \\
\text { makan } \\
\text { - Ny.C tampak } \\
\text { lemas } \\
\text { - Wajah Ny.C } \\
\text { tampak lemas } \\
\text { - Wajah Ny.C } \\
\text { tampak pucat } \\
\text { - Pemeriksaan } \\
\text { TTV } \\
\text { TD: } 150 / 90 \\
\text { mmhg } \\
\mathrm{N}: 88 \times \text { x /menit } \\
\text { P : } 20 \times \text { /menit } \\
\text { S: } 366^{0} \mathrm{C} \\
\text { Kgd sewaktu } \\
200 \mathrm{mg} / \mathrm{dl}\end{array}$ & \begin{tabular}{ll|} 
- & Tampak \\
cemas dan \\
tidak \\
tenang \\
- Kadang \\
Ny.C \\
tampak \\
murung \\
- Ny.C \\
tampak \\
gelisah \\
- Ny.C \\
tampak \\
pasif dalam \\
menerima \\
perawatan \\
Ny.C \\
menunduk saat \\
bercerita
\end{tabular} & \begin{tabular}{|l} 
- Hubungan \\
Ny.C dengan \\
suami baik \\
- Ny.C kurang \\
bersosialisasi \\
dengan \\
keluarga \\
Ny.C tetap \\
mengikuti \\
program \\
pengobatan \\
yang \\
diberikan \\
kepadanya \\
akan tetapi \\
sikap Ny.C \\
pasif dalam \\
menerima \\
perawatan
\end{tabular} & $\begin{array}{l}\text { - Kurang } \\
\text { pengetahuan }\end{array}$ \\
\hline
\end{tabular}




\begin{tabular}{|c|c|c|c|c|c|c|}
\hline $\begin{array}{l}\text { SOSIAL } \\
\text { BUDAYA } \\
\text { - Sering } \\
\text { memikirkan } \\
\text { anak-anak } \\
\text { yang masih } \\
\text { Yang jauh } \\
\text { dari rumah } \\
\text { merasa } \\
\text { kasihan } \\
\text { kepada } \\
\text { suami yang } \\
\text { harus } \\
\text { menjaga dan } \\
\text { merawatnya } \\
\text { setiap hari. }\end{array}$ & $\begin{array}{l}\text { - Ny.C merasa } \\
\text { tidak berdaya } \\
\text { dengan } \\
\text { keadaannya } \\
\text { sejarang yang } \\
\text { tidak bisa bekerja } \\
\text { bingung } \\
\text { memikirkan anak- } \\
\text { anak yang jauh } \\
\text { merantau } \\
\text { menurut pasien, } \\
\text { dukungan } \\
\text { keluarga nomor } \\
\text { satu } \\
\text { - Ny.C berfikir ia } \\
\text { selalu } \\
\text { merepotkan } \\
\text { suaminya bila } \\
\text { terlalu lama } \\
\text { dalam keadaan } \\
\text { seperti ini } \\
\text { Merasa } \\
\text { Kasihan } \\
\text { kepada suami } \\
\text { yang harus } \\
\text { menjaga dan } \\
\text { merawat pasien. }\end{array}$ & $\begin{array}{l}\text { - Merasa } \\
\text { khawatir dan } \\
\text { sedih kepada } \\
\text { suami yang } \\
\text { merawatnya } \\
\text { setiap hari } \\
\text { - Merasa } \\
\text { bersalah } \\
\text { karena } \\
\text { merasa } \\
\text { merepotkan } \\
\text { suami } \\
\text { - Merasa } \\
\text { bosan } \\
\text { dengan } \\
\text { keadaan } \\
\text { sekarang }\end{array}$ & $\begin{array}{l}\text { - Pusing } \\
\text { - Mual } \\
\text { - Mulut tampak } \\
\text { kering } \\
\text { - Sulit tidur } \\
\text { - Bahu terasa } \\
\text { tegang } \\
\text { - Konstipasi } \\
\text { - Tidak nafsu } \\
\text { makan } \\
\text { - Ny.C tampak } \\
\text { lemas } \\
\text { - Wajah Ny.C } \\
\text { tampak pucat } \\
\text { Pemeriksaan }\end{array}$ & $\begin{array}{l}\text { - Kontak mata } \\
\text { ada tapi tidak } \\
\text { bertahan } \\
\text { lama } \\
\text { - Volume } \\
\text { suara } \\
\text { mengecil } \\
\text { - Ny.C tampak } \\
\text { gelisah }\end{array}$ & $\begin{array}{l}\text { - Hubungan } \\
\text { Ny.C dengan } \\
\text { suami baik } \\
\text { - Hubungan } \\
\text { Ny.C dengan } \\
\text { petugas } \\
\text { kesehatan } \\
\text { baik } \\
\text { - Ny.C tetap } \\
\text { mengikuti } \\
\text { program } \\
\text { pengobatan }\end{array}$ & $\begin{array}{l}\text { - Penampilan } \\
\text { peran tidak } \\
\text { efektif }\end{array}$ \\
\hline
\end{tabular}


3.1.3 Sumber Koping

\begin{tabular}{|c|c|c|c|c|c|}
\hline $\begin{array}{c}\text { DIAGNOSA } \\
\text { KEPERAWATAN }\end{array}$ & PERSONAL ABILITY & SOSIAL SUPPORT & $\begin{array}{l}\text { MATERIA } \\
\text { ASSETS }\end{array}$ & $\begin{array}{l}\text { POSITIE } \\
\text { BELIEFS }\end{array}$ & TERAPI \\
\hline Ketidakberdayaan & $\begin{array}{l}\text { - Ny.C mampu } \\
\text { mengungkapkan } \\
\text { perasaan malu } \\
\text { - Ny.C mengatakan bila } \\
\text { cemasnya memuncak } \\
\text { maka ia akan } \\
\text { mengambil air wudhu } \\
\text { dan sholat }\end{array}$ & $\begin{array}{l}\text { - Ny.C mendapat } \\
\text { dukungan dari } \\
\text { keluarga untuk } \\
\text { kesembuhannya } \\
\text { terutama dari } \\
\text { suaminya } \\
\text { - Suami dan adik } \\
\text { Ny.C bergantian } \\
\text { merawat pasien }\end{array}$ & $\begin{array}{l}\text { - Sosial ekonomi } \\
\text { Ny.C menengah } \\
\text { Pengobatan } \\
\text { ditanggung BPJS } \\
\text { - Jarak rumah Ny.C } \\
\text { dengan tempat } \\
\text { pelayanan } \\
\text { kesehatan lebih } \\
\text { kurang } 500 \text { meter }\end{array}$ & $\begin{array}{l}\text { - Ny.C percaya } \\
\text { bahwa petugas } \\
\text { kesehatan akan } \\
\text { membantunya } \\
\text { - Ny.C berharap } \\
\text { cepat sembuh agar } \\
\text { tidak merepotkan } \\
\text { Suaminya }\end{array}$ & $\begin{array}{l}\text { Terapi spesialis: } \\
\text { - } \text { Relaksasi } \\
\text { progresif } \\
\text { - Psikoedukasi } \\
\text { keluarga } \\
\text { - } \text { Behavior } \\
\text { therapy } \\
\text { - Psikoedukasi } \\
\text { keluarga }\end{array}$ \\
\hline
\end{tabular}




\begin{tabular}{|c|c|c|}
\hline $\begin{array}{|ll|}\text { Penampilan } & \text { peran } \\
\text { tidak efektif } & \end{array}$ & $\begin{array}{l}\text { - Ny.C dapat } \\
\text { menyebutkan } \\
\text { penyebab } \\
\text { penampilan peran } \\
\text { tidak efektif } \\
\text { - Ny.C } \\
\text { menganggap } \\
\text { suami tidak } \\
\text { mampu sebagai } \\
\text { pengganti akibat } \\
\text { kondisi yang } \\
\text { berubah }\end{array}$ & $\begin{array}{l}\text { - Ny.C selalu } \\
\text { berdoa untuk } \\
\text { kesembuhan } \\
\text { penyakitnya } \\
\text { - Ny.C yakin, bila } \\
\text { ia mengikuti } \\
\text { petunjuk dan } \\
\text { saran dari petugas } \\
\text { kesehatan maka ia } \\
\text { akan cepat } \\
\text { sembuh san yakin suami } \\
\text { - Ny.C yarga } \\
\text { dan keluarga } \\
\text { mendukung } \\
\text { supaya lekas } \\
\text { sembuh } \\
\text { - Ny.C percaya } \\
\text { bahwa petugas } \\
\text { kesehatan akan } \\
\text { membantunya } \\
\text { - Ny.C berharap } \\
\text { cepat sembuh } \\
\text { agar tidak } \\
\text { merepotkan } \\
\text { suaminya }\end{array}$ \\
\hline
\end{tabular}




\begin{tabular}{|c|c|c|c|c|c|}
\hline Kurang pengetahuan & 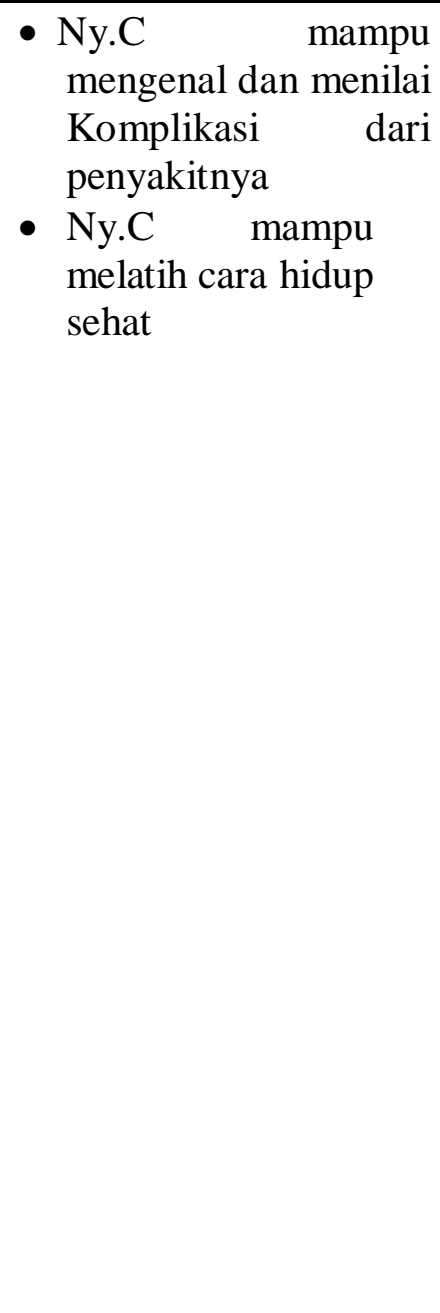 & $\begin{array}{l}\text { - Ny.C mendapat } \\
\text { dukungan dari } \\
\text { keluarga untuk } \\
\text { kesembuhannya } \\
\text { terutama dari } \\
\text { suaminya } \\
\text { - Suami dan keluarga } \\
\text { Ny.C bergantian } \\
\text { menjaga dan } \\
\text { mengunjungi } \\
\text { pasien } \\
\text { Tetangga Ny.C } \\
\text { dan teman di } \\
\text { tempat kerja juga } \\
\text { banyak yang } \\
\text { mengunjungi } \\
\text { pasien }\end{array}$ & $\begin{array}{l}\text { - Sosial ekonomi } \\
\text { Ny.C menengah } \\
\text { - Ny.C tinggal di } \\
\text { rumah sendiri, } \\
\text { rumah permanen } \\
\text { - Sarana dan } \\
\text { prasarana } \\
\text { tersedia } \\
\text { - Biaya } \\
\text { pengobatan } \\
\text { ditanggung oleh } \\
\text { asuransi BPJS } \\
\text { Jarak rumah Ny C } \\
\text { dengan tempat } \\
\text { pelayanan } \\
\text { kesehatan (RSMM) } \\
\text { lebih kurang } 500 \\
\text { meter }\end{array}$ & $\begin{array}{l}\text { - Ny.C percaya } \\
\text { bahwa petugas } \\
\text { kesehatan akan } \\
\text { membantunya } \\
\text { - Ny.C berharap } \\
\text { cepat sembuh } \\
\text { agar tidak } \\
\text { merepotkan } \\
\text { suaminya } \\
\text { - Ny.C selalu } \\
\text { berdoa untuk } \\
\text { kesembuhan } \\
\text { penyakitnya } \\
\text { Ny.C yakin, bila } \\
\text { ia mengikuti } \\
\text { petunjuk dan } \\
\text { saran dari } \\
\text { petugas } \\
\text { kesehatan maka } \\
\text { ia akan cepat } \\
\text { sembuh } \\
\text { Ny.C yakin } \\
\text { suami dan } \\
\text { keluarga } \\
\text { mendukung } \\
\text { supaya lekas } \\
\text { sembuh }\end{array}$ & 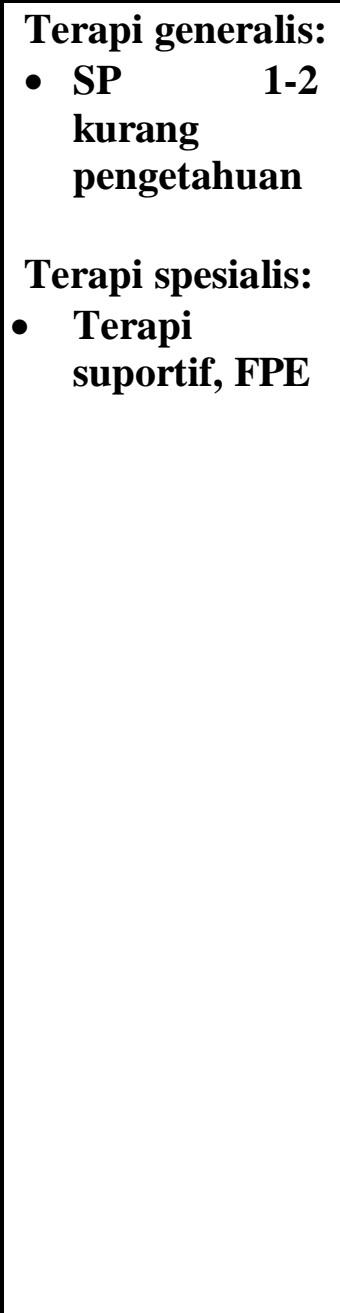 \\
\hline
\end{tabular}




\subsubsection{Mekanisme Koping}

\section{HAL YANG \\ DILAKUKAN}

- Ny.C mengatakan bila ada masalah, maka ia akan membicarakan dengan suami dan keluarga untuk mencari jalan keluarnya

- Bila sakit Ny.C berobat ke pelayanan kesehatan

- Ny.C taat menjalankan ibadah sesuai dengan keyakinannya

- Ny.C selalu berdoa kepada Allah SWT untuk kesembuhannya

\section{ANALISA}

- Konstruktif:

$\checkmark$ Ny.C mengatakan bila ada masalah, maka ia akan membicarakan dengan suami dan keluarga untuk mencari jalan keluarnya

$\checkmark$ Bila sakit Ny.C berobat ke pelayanan kesehatan

$\checkmark$ Ny.C taat menjalankan ibadah sesuai dengan keyakinannya

$\checkmark$ Ny.C selalu berdoa kepada Allah SWT untuk kesembuhannya.

- Destruktif :- 


\subsubsection{Status Mental}

\begin{tabular}{|l|l|}
\hline 1. Penampilan & Bersih, rapi, tidak tercium bau, Ny.C tampak lemas \\
\hline 2. Pembicaraan & Susah berbicara akibat dari kelumpuhan sebelah dari anggota tubuh (afasia ) \\
\hline 3. Aktivitas motoric & Tubuh sulit digerakkan \\
\hline 4. Interaksi selama wawancara & Cukup kooperatif, meskipun afasia \\
\hline 5. Alam perasaan & Sedih, merasa cemas ,takut dan bingung mengenai kondisi penyakit, suami dan anak-anaknya \\
\hline 6. Afek & Datar \\
\hline 7. Persepsi & Ny.C mengalami gangguan dalam proses sensori-persepsi \\
\hline 8. Isi piker & Mengalami masalah karena sebagian memori terlupakan \\
\hline 9. Proses piker & masalah karena sebagian memori terlupakan \\
\hline 10. Tingkat kesadaran & Ny.C dapat menyebutkan kembali nama suami \\
\hline 11. Daya ingat & Ny.C tidak dapat mengingat beberapa kejadian dalam hidupnya \\
\hline 12. Kemampuan berhitung & Kemampuan berhitung cukup baik \\
\hline 13. Penilaian & Ny.C belum mampu menyebutkan bagaimana caranya agar Ny.C lekas sembuh \\
\hline 14. Daya tilik diri & $\begin{array}{l}\text { Ny.C menyadari bahwa saat ini ia sdang sakit, Ny.C hanya bisa berdoa supaya lekas sembuh agar } \\
\text { tidak terus merepotkan suaminya. Ny.C menyadari ia memiliki suami, anak-anak dan keluarga yang } \\
\text { menyayanginya dan mendukung kesembuhannya }\end{array}$ \\
\hline
\end{tabular}

Kesimpulan : Mental Status Examination (MSE) tidak ada masalah gangguan jiwa, gangguan Ny.C lebih kepada Gangguan Mental

Emosional (GME/Psikososial) 


\subsection{Diagnosa Dan Terapi}

\begin{tabular}{|l|l|}
\hline DIAGNOSA KEPERAWATAN DAN TERAPI KEPERAWATAN & DIAGNOSA MEDIS \\
\hline 1. Ansietas & Stroke \\
Sp1: mendiskusikan penyebab,terjadinya proses terjadi, tanda gejala, akibat & \\
Sp2 : melatih teknik releksasi fisik & \\
Sp3: melatih mengatasi ansietas dengan distraksi dan hipnotis lima & \\
Sp4 : melatih mengatasi ansietas memalui kegiatan spritual & \\
Terapi Spesialis: TS, PMR, Logo ACT & \\
2. Penampilan peran tidak efektif & \\
Terapi perilaku & \\
3. Kurang pengetahuan & \\
Terapi suportif, FPE & \\
\hline
\end{tabular}

\subsection{Implementasi Tindakan Kperawatan Dan Evaluasi}

\begin{tabular}{|c|c|}
\hline IMPLEMENTASI TINDAKAN KEPERAWATAN & EVALUASI \\
\hline $\begin{array}{l}\text { Tanggal : } 05 \text { Oktober } 2021 \\
\text { Jam: } 10.00 \text { wib } \\
\text { a. Kaji tanda dan gejala ansietas dan kemampuan pasien mengurangi } \\
\text { kecemasan } \\
\text { b. Jelaskan tanda dan gejala, penyebab dan akibat dari kecemasan } \\
\text { c. Latihan cara mengatasi kecemasan : } \\
\text { 1) Teknik relaksasi napas dalam } \\
\text { 2) Distraksi : bercakap-cakap hal positif } \\
\text { 3) Hipnotis } 5 \text { jari fokus padahal-hal yang positif } \\
\text { d. Bantu pasien melakukan latihan sesuai dengan jadwal kegiatan. }\end{array}$ & $\begin{array}{ll}\text { S : } & \\
\text { - } & \text { Pasien mengatakan : merasa lebih tenang tetapi } \\
& \text { belum sepenuhnya cemasnya hilang } \\
\text { - } & \text { Pasien mengatakan ia mampu mengindentifikasi } \\
& \text { situasi yang mencetus ansietas } \\
\mathbf{O}: & \\
\text { - Pasien tampak rileks dan tidak gelisah lagi } \\
\text { - Klen mampu menjelaskan kembali penjelasan } \\
& \text { yang sudah diberikan } \\
\text { A : Ansietas }(+)\end{array}$ \\
\hline
\end{tabular}




\begin{tabular}{|c|c|}
\hline & $\begin{array}{l}\text { P : } \\
\text { - } \quad \text { Evaluasi SP-1 dan SP-2 } \\
\text { - } \quad \text { Latihan cara mengatasi kecemasan : } \\
\text { - Teknik relaksasi napas dalam } \\
\quad \text { - Distraksi : bercakap-cakap hal positif } \\
\quad \text { - Hipnotis } 5 \text { jari fokus padahal-hal yang positif } \\
\text { - Bantu pasien melakukan latihan sesuai dengan jadwal } \\
\text { kegiatan }\end{array}$ \\
\hline $\begin{array}{l}\text { Tanggal : } 06 \text { Oktober } 2021 \\
\text { Jam : } 10.00 \text { wib } \\
\text { a. Latihan cara mengatasi kecemasan : } \\
\text { - Teknik relaksasi napas dalam } \\
\text { - Distraksi : bercakap-cakap hal positif } \\
\text { - Hipnotis } 5 \text { jari fokus padahal-hal yang positif } \\
\text { b. Bantu pasien melakukan latihan sesuai dengan jadwal kegiatan. }\end{array}$ & $\begin{array}{l}\text { S : } \\
\text { - } \text { Pasien mengatakan : merasa lebih tenang dan } \\
\text { - } \text { Pasien menasa cemas lagi } \\
\text { situasi yang mencetus ansietas } \\
\text { - Pasien mengatakan sudah bisa melakukan teknik } \\
\text { - } \text { Parik napas dalam } \\
\text { Pasien mengatakan sudah bisa melakukan teknik } \\
\text { - } \text { distraksi } \\
\\
\text { Pasien mengatakan sudah bisa melakukan teknik } \\
\text { O : } \\
\text { - Pasien tampak rileks dan tidak gelisah lagi } \\
\text { - Klen mampu menjelaskan kembali penjelasan } \\
\text { - } \text { yang sudah diberikan } \\
\text { - Pasien mampu melakukan teknik napas dalam } \\
\text { - Pasien mampu melakukan distraksi } \\
\text { Pasien mampu melakukan hipnotis } 5 \text { jari }\end{array}$ \\
\hline
\end{tabular}




\begin{tabular}{|c|c|}
\hline & $\begin{array}{l}\text { A : Ansietas (+) } \\
\text { P : } \\
\text { - } \text { Bantu pasien melakukan latihan sesuai dengan } \\
\text { jadwal kegiatan } \\
\text { - Terapi Perilaku } \\
\text { - Terapi Kognitif } \\
\text { - Pendidikan Kesehatan }\end{array}$ \\
\hline $\begin{array}{l}\text { Tanggal : } 07 \text { Oktober } 2021 \\
\text { Jam : } 10.00 \text { wib } \\
\text { a. Latihan cara mengatasi kecemasan : } \\
\text { - Teknik relaksasi napas dalam } \\
\text { - Distraksi : bercakap-cakap hal positif } \\
\text { - Hipnotis } 5 \text { jari fokus padahal-hal yang positif } \\
\text { b. Bantu pasien melakukan latihan sesuai dengan jadwal kegiatan. }\end{array}$ & $\begin{array}{l}\text { S : pasien mengatakan kecemasan sedikit berkurang, } \\
\text { mampu mengatas kecemasan, dengan intervensi yang } \\
\text { diberikan } \\
\text { O: Pasien masih terlihat dengan kecemasan yang belum } \\
\text { teratasi, tidak mampu melakukan teknik relaksasi fisik } \\
\text { Tarik nafas dalam, dan distraksi hipnotis lima jari } \\
\text { A: kecemasan pasien belum Teratasi } \\
\text { P: Intervensi dilanjutkan }\end{array}$ \\
\hline $\begin{array}{l}\text { Tanggal : } 08 \text { Oktober } 2021 \\
\text { Jam : } 10.00 \text { wib } \\
\text { a. Latihan cara mengatasi kecemasan : } \\
\text { - Teknik relaksasi napas dalam } \\
\text { - Distraksi : bercakap-cakap hal positif } \\
\text { - Hipnotis } 5 \text { jari fokus padahal-hal yang positif } \\
\text { b. Bantu pasien melakukan latihan sesuai dengan jadwal kegiatan }\end{array}$ & $\begin{array}{l}\text { S: pasien masih malu akan penyakitnya, namun pasien } \\
\text { terihat mau berkomunikasi kepada suami. } \\
\text { O: pasien terlihat masih merasa harga dirinya rendah, } \\
\text { tidak mampu mengidentifikasi masalahnya sendiri } \\
\text { A: harga diri pasien belum teratasi } \\
\text { P: intervensi dilanjutkan }\end{array}$ \\
\hline $\begin{array}{l}\text { Tanggal : } 09 \text { Oktober } 2021 \\
\text { Jam : } 10.00 \text { wib } \\
\text { a. } \text { Latihan cara mengatasi kecemasan : } \\
\text { - Teknik relaksasi napas dalam } \\
\text { - Distraksi : bercakap-cakap hal positif } \\
\text { - Hipnotis } 5 \text { jari fokus padahal-hal yang positif }\end{array}$ & $\begin{array}{l}\text { S: Pasien mengatakan: ansietasnya belum teratasi karena } \\
\text { pasien masih beum merasa tenang, masih cemas, dan } \\
\text { masih merasa tidak berdaya. } \\
\text { O: pasien terlihat masih merasa tidakberdaya akan } \\
\text { penyakitnya, belum mampu mengindentifikasi situasi } \\
\text { pecentus dari ansietas }\end{array}$ \\
\hline
\end{tabular}




\begin{tabular}{|l|l|}
\hline b. Bantu pasien melakukan latihan sesuai dengan jadwal kegiatan & $\begin{array}{l}\text { A: Ketidakberdayaan pasien belum berkurang } \\
\text { P: intervensi dilanjutkan }\end{array}$ \\
\hline $\begin{array}{l}\text { Tanggal : } 10 \text { Oktober } 2021 \\
\text { Jam : } 10.00 \text { wib }\end{array}$ & $\begin{array}{l}\text { S: pasien sudah mampu mengidentifikasi masalah, pasien } \\
\text { mampu melakukan teknik Tarik nafas dalam secara } \\
\text { mandiri }\end{array}$ \\
- Teknik relaksasi napas dalam & $\begin{array}{l}\text { O: pasien terlihat antusias, mengidentifikasi masalahnya } \\
\text { sendiri } \\
\text { - Distraksi : bercakap-cakap hal positif } \\
\text { - Hipnotis } 5 \text { jari fokus padahal-hal yang positif } \\
\text { b.Bantu pasien melakukan latihan sesuai dengan jadwal kegiatan. }\end{array}$ \\
& $\begin{array}{l}\text { P: intervensi dihentikan } \\
\end{array}$ \\
\hline
\end{tabular}




\section{BAB 4}

\section{PEMBAHASAN}

Pada pembahasan ini penulis membahas tentang kesenjangan yang ditemukan antara teori dengan kasus yang penulis buat, pada pembahasan ini penulis menganalisa tentang hambatan yang ditemukan pada saat penulis melakukan asuhan keperawatan pada pasien.

Pada tahap pengkajian ditemukan adanya beberapa kesenjangan diantaranya respon perilaku. Pada respon perilaku menurut teori tanda gejalanya adalah rasa terbakar di jantung, sering kencing dan kulit terasa panas, sedangkan pada kasus adalah pasien tidak menunjukkan respon perlaku seperti pada teori. Hal ini disebabkan karena kecemasan yang dialami pasien masih tahap sedang.

Pada tahap diagnosa dan perencanaan tidak ditemukan kesenjangan antara teori dan kasus dimana diagnosa yang diangkat adalah kecemasan, penampilan peran tidak efektif dan kurang pengetahuan sama halnya dengan intervensi, rencana asuhan keperawatan pada Ny. C dimulai setelah data terkumpul yang didapat dari hasil pengkajian. Tindakan yang diberikan pun yaitu terapi dan pendidikan kesehatan. Pembahasan pada implementasi penulis melaksanakan tindakan keperawatan sesuai dengan rencana yang sudah ditetapkan. Sebelumnya penulis melakukan kontrak waktu kepada pasien untuk melakukan implementasi, selama tahap implementasi tidak ada hambatan dan pasien kooperatif dalam mengikuti terapinya.

Pada tahap evaluasi penulis hanya dapat melaksanakan diagnosa keperawatan yang pertama saja. Pada evaluasi yang diharapkan adalah :

a. Membina hubungan saling percaya

b. Mengenali dan mengekspresikan emosinya

c. Mampu mengenal ansietas

d. Mampu mengatasi ansietas melalui teknik releksasi

e. Mampu mengatasi ansietas dengan distraksi

f. Mampu mengatasi ansietas melalui hipnotis lima jari

g. Mampu mengatasi ansietas melalui kegiatan spritual 


\section{BAB 5}

\section{PENUTUP}

\subsection{Kesimpulan}

Berdasarkan konsep asuhan keperawatan yang telah disusun dan dilaksanakan kepada Ny.C dimiliki dari pengkajian, rumusan masalah, perencanaan, pelaksanaan hingga evaluasi didapat hasil bahwa Ny.C dengan keluhan utama malu akan penyakit stroke sehingga tidak mampu melakukan aktivitas seperti biasanya data objektif yaitu pasien tampak badan lemas, kesemutan, gatal, gemetaran pusing luka yang lama sembuh, Tekanan darah tinggi Dari masalah masalah diatas maka diperoleh prioritas masalah yang diangkat adalah tentang kebutuhan rasa aman nyaman yang berfokus pada cemas. Kemudian diberikan intervensi secara konsep yaitu terapi teknik relaksasi napas dalam, terapi distraksi, hipnotis lima jari dan pendidikan kesehatan. Dari hasil implementasi ada beberapa intervensi yang berhasil teratasi seperti pasien mengatakan sudah lebih tenang dan cemas nya sedikit berkurang dan mampu mengenali gejala, tanda, penyebab dan akibat dari kecemasan. Sedangkan pasien masih bingung dalam melakukan terapi hipnotis lima jari maka intervensi dilanjutkan.

\subsection{Saran}

Diharapkan bagi perawat selalu berkoordinasi dengan tenaga kesehatan lainnya dalam memberikan asuhan keperawatan agar lebih maksimal terkhusus pada pasien dengan kecemasan pada pasien stroke 


\section{DAFTAR PUSTAKA}

1. Susilawati, F., \& Nurhayati, S. K. (2018). Faktor Risiko Kejadian Stroke. Jurnal Ilmiah Keperawatan Sai Betik, 14(1), 41-48.

2. Maria, I. (2020). Hubungan Pelaksanaan Range of Motion Dengan Risiko Dekubitus Pada Pasien Stroke. Jurnal Keperawatan Suaka Insan (Jksi), 5(1), 109-115.

3. Suwaryo, P. A. W., Widodo, W. T., \& Setianingsih, E. (2019). Faktor Risiko yang Mempengaruhi Kejadian Stroke. Jurnal Keperawatan, 11(4), 251-260. https://doi.org/10.32583/keperawatan.v11i4.530

4. Ramadia, A., Keliat, B. A., \& Wardani, I. Y. (2019). Hubungan Kemampuan Mengubah Pikiran Negatif Dengan Depresi Dan Ketidakberdayaan Pada Pasien Stroke. Al-Asalmiya Nursing: Jurnal Ilmu Keperawatan

5. Nuraliyah, S., \& Burmanajaya, B. (2019). Mekanisme Koping dan Respon Ketidakberdayaan pada Pasien Stroke.

6. Pardede, J. A. (2020). Konsep Ketidakberdayaan. doi: 10.31219/osf.io/hd3g6

7. Wahyudi, U., \& Burnamajaya, B. (2020). Konsep Diri dan Ketidakberdayaan Berhubungan dengan Risiko Bunuh Diri pada Remaja yang Mengalami Bullying. Jurnal Keperawatan Jiwa (JKJ): Persatuan Perawat Nasional Indonesia, 8(1), 1-8.

8. Yusuf, R. S., \& Wardan, I. Y. (2015). Analisis Praktik Klinik Keperawatan Kesehatan Masyarakat Perkotaan Ketidakberdayaan Pada Pasien Diabetes Melitus Tipe Ii Di Ruang Antasena Rumah Sakit Dr. H. Marzoeki Mahdi Bogor. Jurnal Keperawatan Jiwa (JKJ): Persatuan Perawat Nasional Indonesia, 3(2), 61-69.

9. Jannah, N., \& Putri, Y. S. E. (2015). Penerapan teknik berpikir positif dan afirmasi positif pada pasien ketidakberdayaan dengan gagal jantung kongestif. Jurnal Keperawatan Jiwa (JKJ): Persatuan Perawat Nasional Indonesia, 3(2), 30-39. https://doi.org/10.26714/jkj.3.2.2015.30-39

10. Ummah, T., Wardani, I. Y., \& Hargiana, G. (2018). Asuhan Keperawatan Psikososial: Ketidakberdayaan Pada Pasien Dengan Gagal Jantung. Jurnal Keperawatan, 10(2), 138-146. https://doi.org/10.32583/keperawatan.10.2.2018.138-146

11. Azari, A. A., \& Zururi, M. I. (2021). Faktor-Faktor Yang Berhubungan Dengan Depresi Pada Lansia. Medical Jurnal Of Al Qodiri, 6(2), 66-72.

12. Pardede, J. A., Hutajulu, J., \& Pasaribu, P. E. (2020). Harga Diri dengan Depresi Pasien Hiv/aids. Jurnal Media Keperawatan: Politeknik Kesehatan Makassar, 11(01).https://doi.org/10.32382/jmk.v11i1.1538. 
13. Pardede, J. A. (2020). Standar Asuhan Keperawatan Jiwa Dengan Masalah Kecemasan.

14. Pardede, J. A., Hasibuan, E. K., \& Hondro, H. S. (2020). Perilaku Caring Perawat Dengan Koping Dan Kecemasan Keluarga. Indonesian Journal of Nursing Sciences and Practice, 3(1), 14-22. https://doi.org/10.24853/ijnsp.v3i1.14-22 10.

15. Pardede, J. A., Sitepu, S. F. A., \& Saragih, M. (2018). The Influence of Deep Breath Relaxation Techniques and Five-Finger Hypnotic Therapy on Preoperative Patient Anxiety. Journal of Psychiatry, 3(1), 1-8.

16. PPNI. (2016). Standar Diagnosa Keperawatan Indonesia: Definisi dan Indikator Diagnostik, Edisi 1. Jakarta : DPP PPNI.

17. PPNI (2018). Standar Luaran Keperawatan Indonesia: Definisi dan Kriteria HasilKeperawatan, Edisi 1 Jakarta : DPP PPNI.

18. Sarani, D. (2021). Asuhan Keperawatan Pada Pasien Stroke Non Hemoragik Dengan Masalah Keperawatan Ketidakberdayaan

19. Zai, Y., Bu'ulolo, K., Fajariani, N., Hulu, Y., Gulo, R. E., \& Nurhayati, E. L. (2020). Hubungan Dukungan Keluarga dengan Tingkat Harga Diri pada Penderita Stroke di Rumah Sakit Umum Royal Prima Medan. Jurnal Riset Hesti Medan Akper Kesdam I/BB Medan, 4(2), 66-73.

20. Handayani, D., \& Dominica, D. (2018). Gambaran drug related problems (DRP's) pada penatalaksanaan pasien stroke hemoragik dan stroke non hemoragik di RSUD Dr M Yunus Bengkulu. Jurnal Farmasi dan Ilmu Kefarmasian Indonesia, 5(1), 36-44. http://dx.doi.org/10.20473/jfiki.v5i12018.36-44

21. Hamzah, S. R. M. (2015). Leukocytes Count In The Ischemic And Hemorrhagic Stroke Patient. Jurnal Majority, 4(1).

22. Pardede, J. A. (2020). Terapi Keluarga.

23. Tarigan, F. L. B., Sinaga, L. R. V., \& Pardede, J. A. (2020). The effect of the simulation of Maena dance on knowledge about balanced nutrition among housewives in Hiliwaele I Village, Botomuzoi Sub-district in Nias Regency in the year of 2018. Enfermería Clínica, 30, 144-146.

24. Mutiarasari, D. (2019). Ischemic stroke: symptoms, risk factors, and prevention. Medika Tadulako: Jurnal Ilmiah Kedokteran Fakultas Kedokteran dan Ilmu Kesehatan, 6(1), 60-73.

25. Nuraliyah, S., \& Burmanajaya, B. (2017). Mekanisme Koping dan Respon Ketidakberdayaan pada Pasien Stroke. JURNAL RISET KESEHATAN POLTEKES DEPKES, 39-40. https://doi.org/10.34011/juriskesbdg.v11i1.227 
26. Nugraha, D. W., Dodu, A. E., \& Chandra, N. (2017). Klasifikasi Penyakit Stroke Menggunakan Metode Naive Bayes Classifier (Studi Kasus Pada Rumah Sakit Umum Daerah Undata Palu). semanTIK, 3(2).

27. Purwaningtiyas, P. (2017). Hubungan Antara Gaya Hidup Dengan Kejadian Stroke Usia Dewasa Muda Di RSUD DR. Moewardi Surakarta Skripsi Universitas Muhammadiyah Surakarta.

28. Pramudita, A., \& Pudjonarko, D. (2016). Faktor-Faktor Yang Mempengaruhi Fungsi Kognitif Penderita Stroke Non Hemoragik. Jurnal Kedokteran Diponegoro, 5(4), 460-474. doi.org/10.14710/dmj.v5i4.14242

29. Setiawan, I. D., Trisyani, Y., \& Lumbantobing, V. B. M. (2018). Pengalaman Hidup Pasien Paska Stroke Di Bandung (The Life Experiences of Post-Stroke Patients In Bandung). Journal of Nursing Care and Biomoleculer, 3(1), 42-51. http://dx.doi.org/10.32700/jnc.v3i1.70 